\title{
RAMAH TAMAH
}

\author{
NURUL INDARSIH
}

9173770410137

nurullindarsihh@gmail.com

1. Bentuk Kegiatan

> Ramah Tamah Bersama Masyarakat Desa Bontocini.

2. Lokasi

$>$ Rumah Kepala Desa Bontocini.

3. Hari/Tanggal dan Waktu

> Jum'at, 13 November 2020 pukul 21:00 - selesai.

4. Peserta Yang Dilibatkan

$>$ Kepala Camat Rumbia

$>$ Dosen Pembimbing

$>$ Kepala Desa (Diwakili)

$>$ Aparat Desa

> Masyarakat Desa Bontocini

$>$ Karang Taruna

> Mahasiswa KKLP Yapti Jeneponto.

5. Alasan Diadakannya

> Alasan diadakannya Malam Ramah Tamah ini yaitu untuk silaturahmi dengan masyarakat desa Bontocini, sekaligus penilaian lomba karya barang bekas yang merupakan salah satu program kerja yang kami susun.

6. Tujuan dan Manfaat

> Tujuan dan Manfaat dari Malam ramah tamah ini yaitu untuk mempererat rasa kekeluargaan dan keakraban antar masyarakat serta penarikan secara resmi oleh dosen pembimbing.

7. Deskripsi Kegiatan

> Kegiatan ini dilaksanakan di kediaman kepala desa Bontocini, diawali dengan makan bersama masyarakat desa, setelah itu melaksanakan susunan acara dan diakhiri dengan menyanyi bersama. 
